\title{
KASUS LEDAKAN POPULASI KUMBANG KELAPA PADA PERKEBUNAN RAKYAT DI DESA SUNGAI NYIUR, KECAMATAN TANAH MERAH, KABUPATEN INDRAGIRI HILIR, PROVINSI RIAU
}

\author{
Incidence of Coconut Beetle Population Explosion in Public Plantation in Sungai \\ Nyiur Village, Tanah Merah Sub-Distric, Indragiri Hilir Regency, in Riau Province
}

\author{
Saripah Ulpah $^{1}$, Nana Sutrisna ${ }^{2}$, Fahroji $^{2}$, Suhendri Saputra $^{2}$, Sri Swastika ${ }^{2}$ \\ ${ }^{1}$ Program Studi Agrotechnology,FakultasPertanian Universitas Islam Riau, \\ ${ }^{2}$ Balai Pengkajian Teknologi Pertanian (BPTP) Riau \\ ulpahsaripah@agr.uir.ac.id
}

\begin{abstract}
ABSTRAK
Indragiri Hilir is a district in Riau Province where around $70 \%$ of the population depends on coconut plantations. In 2018, a large population explosion of coconut beetles, Oryctes rhinoceros was reported in several regions in the Province. The population explosion that occurred in Sungai Nyiur Village, Tanah Merah Subdistrict, has caused conflicts between the community who own coconut plantations and oil palm plantation companies in the area related to the source of pest outbreaks. The regional government has formed an independent team to conduct scientific studies to examine this problem. The independent team in charge consisted of 12 personnel involving universities (UIR) and Riau BPTP agricultural institutions. The steps taken include surveys, interviews, field investigation, and trapping. The survey was conducted to determine the epicenter of the attack by evaluating the intensity of the damage visually and with the drone aid. Excavation and inspection of breeding sites were carried out to evaluate the presence and presence of beetles and larvae. Pheromone trap installation is intended to analyze the distribution of coconut beetles. Interviews were carried out both for coconut farmers and staff of oil palm plantation companies related to the chronology of beetle pest explosion and activities carried out on oil palm plantation companies. The findings obtained from the study conducted were presented to both parties in dispute and also the Regional Government of Indragiri Hilir as described in this paper.
\end{abstract}

Keywords: Oryctes rhinoceros, Explosions, Breeding Site, Replanting

\section{ABSTRAK}

Indragiri Hilir merupakan kabupaten di Provinsi Riau dimana sekitar $70 \%$ dari populasinya bergantung pada perkebunan kelapa. Pada tahun 2018, ledakan populasi yang besar dari kumbang kelapa, Oryctes rhinoceros dilaporkan terjadi di beberapa kawasan di Provinsi ini. Ledakan populasi yang terjadi di Desa Sungai Nyiur Kecamatan Tanah Merah, telah menimbulkan konflik antara masyarakat pemilik kebun kelapa dengan perusahaan perkebunan sawit di kawasan ini terkait sumber terjadinya ledakan hama. Pemerintah daerah telah membentuk suatu tim independen untuk melakukan kajian ilmiah untuk menelaah permasalahan ini. Tim independen yang bertugas terdiri dari 12 personel yang melibatkan perguruan tinggi (UIR) dan lembaga pertanian BPTP Riau. Langkah-langkah yang dilakukan meliputi survei, interview, infestigasi lapang, dan trapping. Survei dilakukan untuk menentukan pusat serangan dengan mengevaluasi intensitas kerusakan secara visual dan dengan alat bantu drone. Penggalian dan pemeriksaan tempat berbiak dilakukan untuk mengevaluasi keberadaan dan kumbang dan larvanya. Pemasangan perangkap berferomon ditujukan untuk menganalisa sebaran kumbang kelapa. Interview dilaksanakan baik terhadap petani kelapa maupun staf perusahaan 
perkebunan sawit terkait kronologi ledakan serangan hama kumbang dan aktifitas yang dilakukan pada perusahaan perkebunan sawit. Temuan yang diperoleh dari kajian yang dilakukan dipaparkan kepada kedua belah pihak yang bersengketa dan juga pihak Pemda Indragiri Hilir sebaimana diuraikan dalam paper ini.

Kata kunci: Oryctes rhinoceros, Ledakan, Breeding Site, Replanting

\section{PENDAHULUAN}

Perkebunan kelapa memiliki peran penting bagi ekonomi, social dan budaya dari masyarakat di Kabupaten Indragiri Hilir. Tanaman kelapa yang dijuluki pohon kehidupan, yang mana setiap bagian dari tanaman ini memiliki nilai ekonomi, menjadikan usaha budidaya kelapa di kawasan ini tidak hanya memenuhi kebutuhan domestik, tetapi juga menjadi komoditi yang potensial untuk diekspor ke luar negeri.

Meskipun kelapa berkontribusi penting bagi penghidupan masyarakat di Indragiri Hilir, beberapa faktor telah dilaporkan sebagai faktor pembatas produksi kelapa (Muhartoyo, 2017). Salah satu dari faktor pembatas tersebut adalah ledakan populasi hama kumbang kelapa, Oryctes rhinoceros. Kumbang ini dikenal sebagai hama invasive terutama pada tanaman kelapa dan kelapa sawit (CABI, 2018; Manley, et al. 2018; Sherley, 2000). Hama ini menyebabkan kerugian yang serius sebab serangannya dapat menyebabkan tanaman mati, baik pada tanaman muda dan bahkan tanaman menghasilkan (CABI, 2018; Rao et al., 2018). Ledakan populasi dari hama ini dapat dipicu oleh perubahan yang signifikan dari kondisi lingkungan khususnya ketika tempat berbiak (Breeding sites) dari hama ini tersedia dalam jumlah besar (Abidin et al. 2014; Balitpa, 2010; Bedford, 2014; Marshall and Jackson, 2017).

Di Kabupaten Indragiri Hilir serangan masif dari hama ini dilaporkan terjadi beberapa kawasan. Diperkirakan kerusakan yang terjadi meliputi 1975,5 ha; 1192,5 terserang sedang dan 783 ha terserang berat. Ledakan hama pada perkebunan kelapa rakyat di Desa Sungai Nyiur dan beberapa desa lainnya telah menimbulkan konflik karena masyarakat mengkalim bahwa kerusakan bersumber dari populasi hama yang meningkat akibat aktifitas replanting perkebunan sawit oleh perusahaan di kawasan sekitar mereka (GoRiau.com, 1 September 2017).
Persengketaan yang terjadi di atasi oleh pemerintahan kabupaten Indragiri Hilir dengan membentuk tim independen, dan disepakati oleh fihak yang terkait, yang bertugas malakukan kajian ilmiah terkait sumber terjadinya ledakan hama di kawasan ini. Untuk tujuan inilah kajian ini dilakukan.

\section{BAHAN DAN METODE}

\section{Waktu danTempat}

Kajian ini dilakukan selama 5 bulan, mulai Januari hingga Mai 2019. Investigasi dilakukan di Desa Sungai Nyiur, Kecamatan Tanah Merah, Kabupaten Indragiri hilir; baik pada lahan perkebunan milik masyarakat maupun lahan perkebunan kelapa sawit milik perusahaan.

\section{Kegiatan Survei}

Kegiatan survei dilakukan dengan cara melakukan wawancara dengan petani kelapa yang kebunnya terdampak serangan ledakan populasi kumbang kelapa dan juga staf dari perkebunan yang dianggap aktifitas mereka memicu terjadinya ledakan hama ini. Wawancara terhadap petani kelapa dilakukan terkait kegiatan usaha tani mereka dan pemahaman mereka terhadap hama kumbang kelapa yang menyerang. Sedangkan wawancara terhadap staf perkebunan dilakukan terkait kegiatan mereka dalam hal konversi tanaman kelapa menjadi perkebunan sawit di kawasan terjadinya ledakan hama kumbang kelapa, dan aktifitas yang mungkin terkait dengan terjadinya ledakan hama ini. Informasi yang berhubungan dengan ledakan hama juga didapatkan dari fihak pemerintahan desa terkait.

\section{Investigasi lapang}

Pada perkebunan kelapa rakyat, investigasi lapang dilakukan dengan memeriksa dan menilai kerusakan tanaman melalui penilaian visual 
secara langsung dan dengan bantuan drone. Pemeriksaan tempat berbiak dilakukan di kawasan tanaman yang rusak dilakukan dengan menggali dan membongkar tempat berbiak kemudian mengumpulkan dan menghitung spesimen yang dijumpai. Sampling sistematik dilakukan pada setiap titik dengan interval $100 \mathrm{~m}$ dari batas perkebunan kelapa sawit, dengan cara evaluasi visual. Evaluasi sebaran populasi juga dilakukan dengan memasang perangkap berferomon dengan interval $100 \mathrm{~m}$, dimulai dari perbatasan kebun kelapa sawit dengan kebun kelapa masyarakat.

Di kawasan perkebunan kelapa sawit, kajian lapangan dilakukan dengan memeriksa tempat/bahan yang berpotensi menjadi tempat berbiak dari kumbang kelapa. Disamping itu, observasi juga dilakukan terhadap tanaman sawit hasil replanting.

\section{Pemaparan Temuan Kajian}

Setelah melakukan dua kali kunjungan dan asesmen lapangan ke masing-masing perkebunan kelapa rakyat dan perusahaan perkebunan sawit, data yang berhasil dikumpulkan dipelajari dengan seksama. Didukung dengan informasi ilmiah yang cukup terhadap data yang diperoleh, simpulan temuan diformulasikan dan disajikan ke masing-masing fihak dengan difasilitasi oleh aparat pemerintah daerah Kabupaten Indragiri hilir.

\section{HASIL DAN PEMBAHASAN}

\section{Informasi Umum Mengenai Desa Sungai Nyiur dan Perusahaan Perkebunan Sawit}

Desa Sungai Nyiur terletak di Kecamatan Tanah Merah dengan luas wilayah $\pm 37.95 \mathrm{~km}^{2}$. Jarak tempuh Desa Sungai Nyiur dari ibu kota kecamatan terdekat $20 \mathrm{~km}$, dengan waktu tempuh 20 menit, sedangkan waktu tempuh ke ibu kota kabupaten 45 menit. Berdasarkan status sosial ekonomi petani kelapa terdampak kumbang tanduk yang terlibat dalam penelitian ini, diketahui sebanyak $87 \%$ petani berpendidikan tingkat SD, tingkat SMP 6,5\% dan 6,5\% hingga tingkat SMA. Namun demikian, dilihat dari pengalaman berkebun $80 \%$ responden telah berkebun kelapa selama lebih dari 10 tahun. Berdasarkan status kepemilikan lahan, seluruhnya merupakan milik pribadi. Berdasarkan luas lahan yang digarap, 53\% responden menggarap 1-5 ha lahan dan $47 \%$ menggarap lebih dari 5 ha lahan. Varietas kelapa yang diusahakan di Desa Sungai Nyiur merupakan varietas kelapa lokal. Berdasarkan umur tanaman diketahui bahwa 57\% tanaman merupakan tanaman sudah menghasilkan (TM) dan $43 \%$ lahan merupakan tanaman belum menghasilkan (TBM).

Perusahaan Perkebunan sawit yang ada di kawasan ini diketahui sebagai PT. Krisna Kereta Kencana (K3), Group Oscar yang berdiri tahun 2014 atas permintaan masyarakat Desa Sungai Nyiur untuk menyelamatkan lahan seluas 12.000 ha yang selalu tergenang air sungai. Perusahaan berdiri dengan pola inti plasma dengan sistem bagi hasil $65 \%$ untuk perusahaan dan $35 \%$ untuk masyarakat. Izin usaha perusahaan seluas 17.000 ha baru dikerjakan seluas 8.000 ha. Penanaman pertama pada tahun 2015, dimana 175 ha sudah panen.

\section{Hasil Investigasi Lapangan}

Berdasarkan observasi di lapangan, tingkat serangan hama kumbang kelapa berkisar antara 50-100\%. Tingkat serangan ini dipengaruhi jarak antara kebun petani dengan kebun milik perusahaan, dimana petani yang kebunnya mengalami serangan berat terletak pada radius 100 meter dari batas lahan bukaan perusahaan. Informasi lainnya yang terkait dengan ledakan hama kumbang kelapa disajikan pada Tabel 1.

Dari observasi lapangan didapati kerusakan tanaman kelapa yang tinggi umumnya berkisar $50-100 \%$. Kerusakan demikian cenderung terjadi apabila ledakan populasi kumbang kelapa, Oryctes rhinoceros, tidak segera diredakan (Chung, 2012; Marshal et al., 2016).

Gejala kerusakan yang diakibatkan oleh kumbang ini sangat jelas (Gambar 1.), terlihat anak daun yang membuka pada pelepah terpotong membentuk seperti kipas dan ditemukannya lubang gerekan pada pangkal pelepah (ACIAR, 2017; Domberg, 2015). 
Tabel 1. Data kebun kelapa yang terserang kumbang tanduk di Desa Sungai Nyiur

\begin{tabular}{llr}
\hline Uraian & & $(\%)$ \\
\hline Umur Tanaman & TM & $57 \%$ \\
Varietas & TBM & $43 \%$ \\
Jarak Kebun - perusahaan & Kelapa local & $100 \%$ \\
& $<100 \mathrm{~m}$ & $20 \%$ \\
& $100-500 \mathrm{~m}$ & $40 \%$ \\
Persentase Serangan & $501-1000 \mathrm{~m}$ & $6.6 \%$ \\
& $>1000 \mathrm{~m}$ & $33,34 \%$ \\
& $100 \%$ & $25 \%$ \\
& $>50 \%$ & $50 \%$ \\
\hline
\end{tabular}
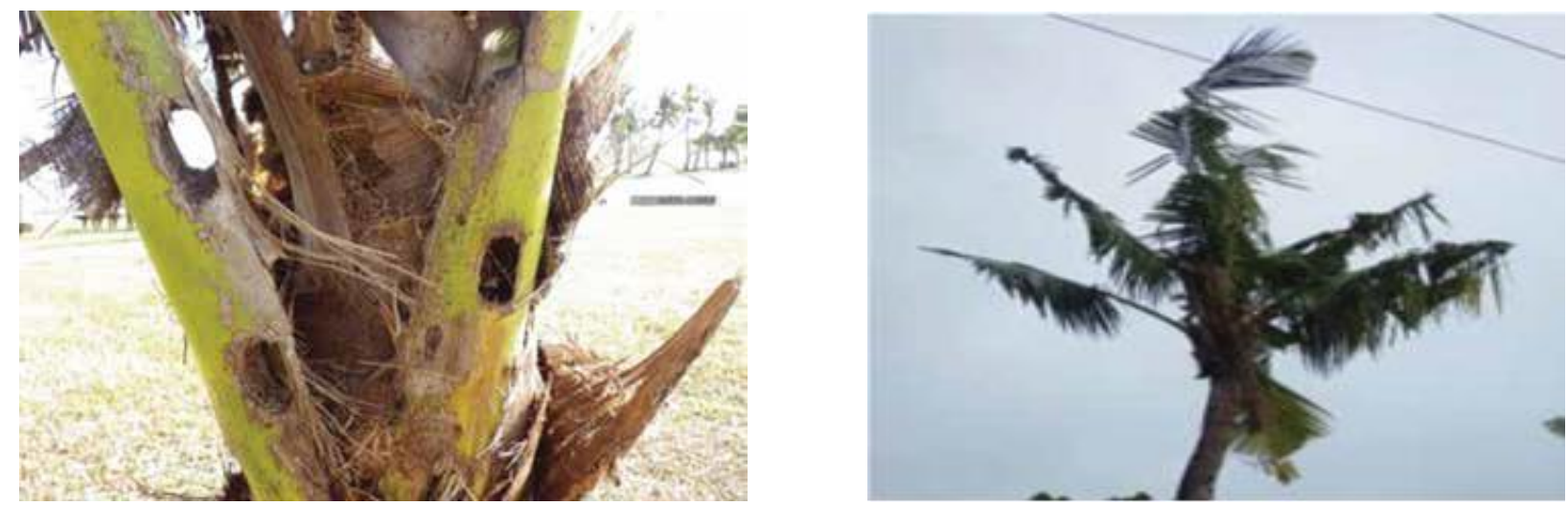

Gambar 1. Gejala kerusakan oleh Oryctes rhinoceros pada tanaman kelapa

Seluruh tanaman pada jarak pengamatan 0400 meter dari kebun perusahaan menunjukkan gejala terserang dengan intensitas serangan yang berbeda-beda. Terdapat kecenderungan intensitas

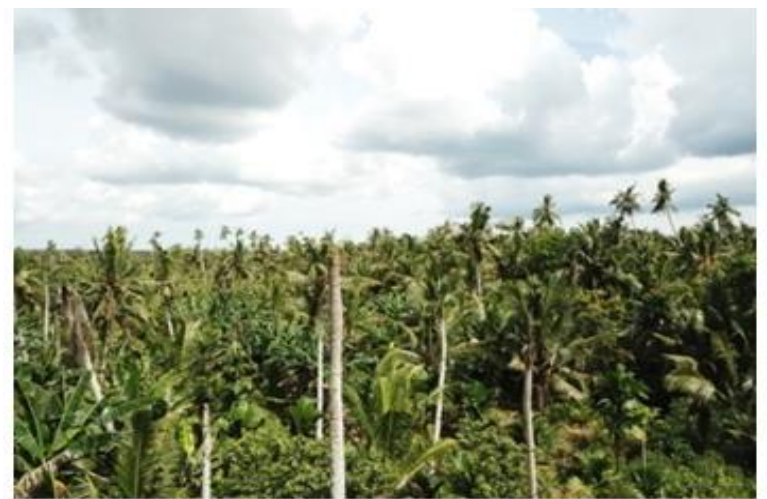

Gambar 2. Kondisi Kelapa Masyarakat Desa Sungai Nyiur yang Berbatasan Langsung Dengan Perusahaan serangan berat terdapat pada kebun kelapa yang dekat/berbatasan langsung dengan perusahaan (Gambar 2).

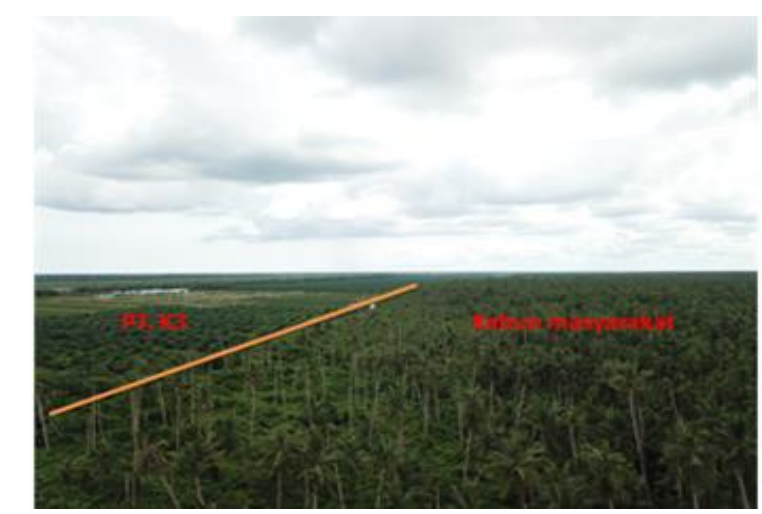

Nyiur yang Berbatasan Langsung Dengan 
Kasus Ledakan Populasi Kumbang Kelapa Pada Perkebunan Rakyat Di Desa Sungai Nyiur, Kecamatan Tanah Merah, Kabupaten Indragiri Hilir, Provinsi Riau

Sebagaimana kecendrungan dari intensitas kerusakan pada tanaman kelapa, jumlah kumbang yang tertangkap dengan menggunakan perangkap berferomon juga menunjukkanbahwa jumlah tangkapan kumbang yang menurun dengan semakin jauhnya letak perangkap dari areal perkebunan sawit hasil replanting dari tanaman sebelumnya, yaitu tanaman kelapa (Tabel 2).

Tabel 2. Tingkat kerusakan tanaman kelapa dan jumlah tangkapan kumbang kelapa pada berbagai jarak dari Kegiatan replanting perusahaan perkebunan sawit

\begin{tabular}{ccc}
\hline Jarak dari perusahaan $(\mathrm{m})$ & Tingkat serangan $(\%)$ & $\begin{array}{c}\text { Tangkapan kumbang } \\
\text { (ekor/3 hari) }\end{array}$ \\
\hline $0-100$ & 100 & 76 \\
$101-200$ & 15 & 5 \\
$201-300$ & 15 & 5 \\
$300-400$ & 10 & 0 \\
\hline
\end{tabular}

Meskipun jumlah tangkapan hama pada perangkap tidak secara definitif menunjukkan besar populasi hama yang ada di suatu kawasan, namun secara relatif dapat menggambarkan jumlah sebaran hama pada suatu kawasan. Penggunaan perangkap berferomon dapat digunakan sebagai sarana untuk mendeteksi kehadiran dan relatif kelimpahan ledakan hama (Moolen and Dowdy (2001, in Ahmad and Kamarudin, 2011), disamping dapat dilakukan sebagai sarana pengendalian populasi hama (Allow et al, 2006); terutama jika dikombinasikan dengan cara pengendalian lainnya seperti pengendalian kimiawi ataupun pengendalian hayati.

Dari hasil pengamatan lapang di lahan bukaan perusahaan banyak ditemukan larva dan imago kumbang dari sisa-sisa bukaan lahan perusahaan, terutama pada sisa batang kelapa pada bukaan lahan perusahaan yang tidak dimanfaatkan.

\section{Temuan Lainnya}

Perusahaan K3 mulai mengkonversi lahan masyarakat menjadi kebun kelapa sawit pada tahun 2015 dengan membangun tanggul pada kawasan yang mengalami intrusi air laut. Kronologi terjadinya gejala dimulai pada tahun 2016 dan serangan berat mulai terjadi pada tahun 2017. Ada beberapa hal mendasar yang menjadi catatan dalam temuan ini. Pertama, waktu terjadinya ledakan hama di kawasan ini sinkron dengan kegiatan perusahaan yang mengakibatkan perubahan lingkungan yang mendukung perkembangan hama kumbang kelapa. Siklus hidup dari serangga, sebagaimana kumbang kelapa ini, dapat sangat bervariasi tergantung pada ketersedian sumber pakan dan kondisi lingkungan (Kamaruddin et al., 2005; Khaliq et al., 2014; Kumashiro et al., 2014). Nuriyanty et al. (2016) melaporkan bahwa di Kabupaten Purbalingga siklus hidup dari hama ini adalah sekitar 4 bulan. Kedua, sebagaian masyarakat memilih beralih dan bergabung dengan perusahaan dengan mengkonversi tanaman kelapa menjadi kelapa sawit karena kondisi tanaman kelapa mereka yang memang kurang baik karena kawasan ini kerap terendam air pasang. Sisa batang kelapa yang tidak dapat dimanfaatkan terbiar di lahan sehingga menjadi tempat berbiak yang sesuai bagi kumbang kelapa. Ketiga, kondisi lingkungan yang tidak mendukung, menyebabkan tanaman kacangan penutup tanah tidak tumbuh baik sehingga sisa tanaman di areal bukaan lahan berpotensi menjadi breeding site hama kumbang. Vegetasi seperti kacangan penutup tanam berperan penting untuk menekan peneluran kumbang betina pada sisa bahan organik yang terdapat akibat replanting, sehingga dapat membatasi siklus hama ini (Wood, 1968; Vargo, 2000; Clark, 2007). Dengan kondisi yang terjadi akibat adanya kegiatan replanting, berbagai publikasi hasil penelitian menunjukkan bahwa replanting kerap memicu terjadinya ledakan hama kumbang kelapa, terutama jika tanaman sebelumnya memang sudah dalam kondisi yang tidak baik (Kamarudin and Wahid, 2004; Pasaribu and de Chenon, 2005; PPKS, 
1996; Abidin et al., 2014; Manjeri et al., 2014; PEI, 2019). Selanjutnya, hal yang paling penting dilakukan yang sering terabaikan dalam kegiatan replanting tanaman jenis palma ini adalah dilakukannya antisipasi, sosialisasi, penyuluhan dan pendampingan terhadap masyarakat disekitar perkebunan yang kemungkinan terdampak ledakan hama kumbang kelapa, karena hama ini dikenal sebagai hama invasive yang populasinya mudah eksplosi jika lingkungan kondusif.

Dari hasil wawancara dengan masyarakat diperoleh informasi bahwa selama ini mereka dapat mengantisipasi ledakan hama kumbang dengan melakukan pembakaran terhadap bahanbahan yang berpotensi menjadi tempat berbiak hama ini. Dengan diberlakukannya larangan kegiatan pembakaran di lahan, maka berbagai pendekatan alternatif harus dilakukan, tentunya dengan bantuan dan kerjasama berbagai fihak termasuk pemerintah daerah. Jika tidak, maka kejadian yang sama dapat terulang kembali dan penanganan hama ini akan menjadi sulit tanaman yang terserang menjadi tempat berbiak sekunder dan penyebarannya menjadi semakin meluas.

\section{KESIMPULAN}

Dengan data dan temuan di atas, disimpulkan bahwa kerusakan yang terjadi pada perkebunan kelapa masyarakat diakibatkan oleh kumbang kelapa, Oryctes rhinoceros, yang dipicu oleh adanya kegiatan replanting yang tidak disertai dengan antisipasi dan penanganan dini.

Peran serta semua pemangku kepentingan beserta Pemerintah Daerah sangat diperlukan dalam menentukan kebijakan, dan pengawasan kegiatan pengelolaan lingkungan demi menghindari timbulnya kerugian yang sama dimasa mendatang.

\section{UCAPAN TERIMAKASIH}

Penulis mengucapkan terimakasih kepada Pemerintah Daerah Indragiri Hilir yang telah membiayai penelitian ini, dan juga kepada masyarakat dan Pihak Perusahaan yang terbuka dan kooperatif sehingga penelitian ini dapat terlaksana dengan baik.

\section{DAFTAR PUSTAKA}

Abidin, C.M.R.Z, Hamid, N.H. and Salim, H. 2014. Population dynamics of Oryctes rhinoceros in decomposing oil palm trunks in area practising zero burning and partial burning. Journal of oil palm research. 26 (2):140-145.

ACIAR. 2017. Coconut rhinoceros beetle Oryctes rhinoceros. Pacific Pests and Pathogens. Fact sheets no 108. http://www.pestnet.org/fact_sheets/cocon ut_rhinoceros_beetle_oryctes_108.htm

Ahmad, S.N. and Kamarudin, N. 2011. Pheromone trapping in controlling key insect pests: Progress and Prospect. Oil palm Bulletin. 62:12-24.

Allou, K. Morin, J.P. Kovassi, P., N'klo, F.H., and Rochat, D. 2006. Oryctes monoceros trapping with synthetic pheromone and palm material in Ivory Coast. Journal of Chemical Ecology. 32:1743-1754.

Balitka. 2010. Pengendalian Kumbang Kelapa. Balai Pengendalian Tanaman Palma, Menado.

Bedford, G. O. 2014. Advances in the control of Rhinoceros beetle, Oryctes rhinoceros, in oil palm. Journal of Oil Palm research. 26(3):183-194.

CABI. 2018. Invasive Species Compendium, Oryctes rhinoceros. CAB International. https://www.invasivespeciesinfo.gov/prof ile/coconut-rhinoceros-beetle. Accessed May 5, 2019.

Chung, G.F. 2012. Effect of pests and diseases on oil palm yield. In Lai,O.M. and Tan,C.P. Palm Oil,Production, Characterization and uses. AOCS Press. Pp. 163-210.

Domberg, M. 2015. Featured Creatures: Coconut Rhinoceros beetle. UF/IFAS. University of Florida. Publication number: EENY629.

Gnanasegaram, M. ,Muhammad, R. and Tan, S.G. 2014. Oryctes rhynoceros beetle, an oil palm pest in Malaysia. Annual Research \& Review in Biology. 4(22):3429-3439.

Kamarudin, N. and Wahid, M.B.. 2004. Immigration and activity of Oryctes 
rhinoceros within a small oil palm replanting area. Journal of Oil Palm Reseach Malaysia. 16(2):64-77

Kamaruddin, N., Wahid, M.B., and Moslim, R. 2005. Environmental factors Affecting the population density of Oryctes rhinoceros in a zero-burn oil palm replant. Journal of Oil Palm Research. 17: 53-63

Khaliq, A., Javed, M., Sohail, M. And Sagheer, M. 2014. Environmental effects on insects and their population dynamics. Journal of Entomology and Zoology Studies. 2(2):1-7.

Kumashiro, B., Hauff, R., Hara, A., Kishimoto, C., and Ishibashi,Y. 2014. Coconut Rhinoceros Beetle, Oryctes rhinoceros (Linnaeus) (Coleoptera:Scarabaeidae). New Pest Advisory No.14-01. Plant Pest Control Branch, Hawaii Department of Agriculture.

Marshall, S.D.G., Moore, A. And Vagalo, M. 2016. A new coconut Rhinoceros beetle biotype threatens coconut and oilpalm in Souteast Asia and the Pasifi. https://cnasre.uog.edu/wp-

content/uploads/2015/09/coconutrhinoceros-beetle.pdf. accessed on Aug 8, 2019

Marshall, S.D and Jackson, T.A. 2017. A new haplotype of the coconut rhinoceros beetle, Oryctes rhinoceros, has escaped biological control by Oryctes rhinoceros nudivirus and is invading Pasific Islands. Journal of Invertebrate Pathology. 149:127-134.

Manley, M., Melzer, J.M., and Spafford, H. 2018. Oviposition preferences and behavior of wild-caught and laboratoryrearedcoconut rhinoceros beetle, Oryctes rhinoceros (Coleoptera:Scarabaeidae) in relation to substrate particle size. Insects. 9(141):1-7.

Muhartoyo, 2017. The Investment opportunities in Coconut Sector in Indragiri Hilir. Cocoinfo International. Vol. 24 No. 2

Nuriyanti, D.D., Widhiono, I . and Suyanto, A. 2016. Faktor-Faktor Ekologis yang berpengaruh terhadap struktur populasi kumbang badak (Oryctes rhinoceros L). Journal of Biosfera Vol 33 (1) :13-21.

Pasaribu, H. And de Chenon, D.. 2005. Strategi pengendalian hama Oryctes rhinocheros di PT Tolan Tiga Indonesia (SIPEF GROUP). Pertemuan Teknis Kelapa Sawit 13-14 September 2005, Sheraton Mustika Hotel. Yogyakarta.

PEI. 2019. Masa replanting kelapa sawit rentan kumbang tanduk. Berita PEI. https://peipusat.org/berita/202/masa-replantingkelapa-sawit-rentan-serangan-kumbangtanduk.html. Accessed: August 8, 2019.

Rao, N.B.V.C., Snehalatharani,A., Nischala,A., Ramanandam,G., and Maheswarappa,H.P. 2018. Management of rhinoceros beetle (Oryctes rhinoceros L.) by biological suppression with Oryctes baculovirus in Andhra Pradesh. Journal of Plantation Crops. 46(2):124127.

Sherley, G. 2000. Invasive species in the Pacific: a technical review and draft regionalstrategy. South pacific Regional Environment Program (SPREP). 190p.

Vargo, A. 2000. Coconut rhinoceros beetle (Oryctes rhinoceros). Agricultural Development in the American Pacific (ADAP). 2000-4. ISBN 1-931436-07-3.

Wood, B.J. 1968. Studies on the effect of ground vegetation on infestation of Oryctes rhinoceros L.) in young oil palm replanting in Malaysia. Bulletin of Entomological Research. 59:85-96. 
